\title{
Legality of the World Bank's Informal Decisions to Expand into the Tax Field, and Implications of These Decisions for Its Legitimacy
}

\author{
Uyanga Berkel-Dorlig*
}

\begin{abstract}
The emergence of global tax governance was triggered by common tax problems, which are now still being faced by international society of nation-states. In the creation of this framework, international institutions have been playing a major role. One of these institutions is the World Bank (Bank). However, those who write about the virtues and vices of the main creators of the framework usually disregard the Bank. This article, therefore, argues that this disregard is not justified because the Bank has also been playing a prominent role. Since two informal decisions taken in the past have contributed to this position of the Bank, the article gives in addition to it answers to the following two related questions: whether these informal decisions of the Bank were legal and if so, what implications, if any, they have for the Bank's legitimacy.
\end{abstract}

Keywords: World Bank, legality, legitimacy, global tax governance, tax policy and tax administration reforms

\section{Introduction}

Taxes are usually a (main) source of income for many modern states ${ }^{1}$ and can thereby have a direct impact on their existence. Consequently, the questions 'whether to tax?' and - if so - 'to what extent?' are considered to be issues that touch upon state sovereignty, which should be respected and protected by international law. However, in today's world, tax issues seem no longer confined to nation-state territory. Rapid technological advancements and acceptance of neoliberal capitalism as

* Ph.D. candidate in the Department of Tax Law, Erasmus School of Law, Erasmus University Rotterdam, The Netherlands. This contribution to Erasmus Law Review has profited from valuable comments given on its earlier drafts from professor A.C.G.A.C. de Graaf, assistant professor M.F. de Wilde and anonymous peer-reviewers. Opinions expressed and any mistakes that one may encounter in it are of the author only. The usual disclaimer applies.

1. There are nowadays - to my knowledge - no states that form their complete budget from sources other than taxes. Even the countries that are listed as 'tax havens' derive a part of their income from taxes such as value added tax, customs and import duties, and sometimes even from corporate income tax. the guiding economic ideology in the world ${ }^{2}$ evoked tax competition among states. ${ }^{3}$ This tax competition has subsequently become one of the causes of disparities between the domestic tax systems of states ${ }^{4}$ leading to the current worldwide aggressive tax planning practice with massive avoidance of direct taxation by multinational enterprises (MNE) and high-net-worth individuals (HNWI). ${ }^{5}$

Tax avoidance and evasion are not new phenomena. Every state with a capitalist economic system that derives its income from taxes has to do with it. ${ }^{6}$ The current avoidance in direct taxation, however, has a far further impact that goes well beyond national borders. Disparities between national tax legislations, sometimes combined with bilateral tax treaties that are supposed to remove double taxation, result in division of the world's wealth among states and within a state in a way that was not always intended with creation of these legal measures. These implications have lifted direct tax issues ${ }^{7}$

2. Before the fall of communism in the Soviet Union in the late 1980s, the Cold War practically divided the world into two rival camps: the West and the East. After its fall, neoliberal capitalism spread from the West to the East.

3. Capitalism considers 'capital' as the major factor of production. Consequently, every state tries to attract as much as capital through many various legal and non-legal measures. One of the legal measures concerns taxation: capital exporting countries try not to burden their capital, while capital importing countries try to attract as much capital as possible through tax legislation and conclusion of tax treaties. The phenomenon that results from these regulatory actions of states in the field of taxation is called in the literature as tax competition.

4. But tax laws of some states - even though not created with the aim of attracting investment or capital - may just differ from each other, which would lead to similar disparities.

5. Strictly speaking, the former is a legal vehicle that aims to benefit individuals, among whom is the latter group.

6. Capitalism is based on the concept of private property - including capital - and the principle of maximisation of gains from this private property. On the one hand, the state should not own anything owing to the concept of private property. On the other hand, the state should not have any - or the least possible - control over private property. This loss of state control is aggravated by the understanding that taxes are a burden on private property, which made the payment of taxes 'undesired' or 'involuntary'. As a result of it, some people (try to) evade or avoid taxation, while taxes - though not directly aimed at maximisation of the gains from the private property or capital - are necessary for the existence of a state that should maintain this capitalist system through the provision of public goods.

7. Indirect taxes are already harmonised on the regional level (e.g. in the European Union) or coordinated by the WTO on the international level. 
from the domestic to the international level by making them one of the major problems - next to environment or security - that have to be tackled on a global level. The global financial and economic crisis in 2008 placed the issue only on top of the political priority list by drawing the attention of the Group of Twenty (G20). ${ }^{8}$

These international direct tax problems can, however, not be solved unless the reign of neoliberal capitalism is ended $^{9}$ or a jointly coordinated action among states is initiated against them that should mitigate the adverse effects of neoliberal capitalism. The former is not an option now as the neoliberal capitalism with its marketoriented economy - though not a perfect one - seems to be a system that is being aspired to by the most people in the world. Furthermore, its current alternatives seem to be various forms of nationalism and communism, all with their own flaws. The latter option - the coordination of tax policies on an international level - has therefore been advocated by many scholars within academia and is being embraced by the world's political and economic leaders as a solution to these problems. ${ }^{10}$ And since international institutions (IIs) ${ }^{11}$ are perfectly suited to such endeavours, a handful of them that were already active in the field of taxation were, accordingly, entrusted with this task. This designation subsequently led to the initiation - as well as supervision of the implementation - of a surge of tax policy norms seemingly aimed at tackling international tax problems. As a result, these IIs created a framework encompassing all these processes, which is termed by some scholars as 'global tax governance' (GTG). ${ }^{12}$

8. Since its London Summit in April 2009, the $\mathrm{G} 20$ has shifted its focus on direct tax issues. See <https://www.theguardian.com/business/2009/ mar/20/g20-tax-haven-blacklist> and <https://www.oecd.org/g20/ topics/taxation/> (last visited: 9 October 2017).

9. Many problems of international taxation result, in my opinion, from the current globalisation, which is based on neoliberal capitalist principles. These neoliberal principles are deregulation (downsizing the role of the government), liberalisation (market liberalisation through, inter alia, removal of trade and capital barriers) and privatisation (privatisation of state properties). Privatisation shifted capital from the state into the private domain. Liberalisation made the capital mobile, and deregulation loosened the control of the state over private capital. However, I do not say with this that ending neoliberal capitalism is the best option to solve these problems.

10. G20 and G-8 have been endorsing the international tax cooperation during their meetings. See I.J.M. Valderrama, 'Legitimacy and the Making of International Tax Law: The Challenges of Multilaterlism', 7 World Tax Journal (2015).

11. I understand by this term not only intergovernmental organisations (IGOs), but also other forms of cooperation such as transnational networks and platforms. As Junne indicated, national governments are usually reluctant to entrust IGOs with this task. Consequently, other alternative structures for international coordination were regarded to be more suitable for that purpose. See G.C.A. Junne, 'International organizations in a period of globalization: New (problems of) legitimacy', in J. Coicaud and V. Heiskanen (eds.), The Legitimacy of international organizations (2001) 189, at 211-19.

12. I refer here to the scholars who understand under this framework processes that create and implement such international norms. However, some scholars seem to understand by this term the norms that are being created. See J. Wouters and K. Meuwissen, 'Global Tax Governance: Work in Progress?', Leuven Centre for Global Governance Studies Working Paper, at 59 (2011) and P. Dietsch and T. Rixen (eds.), Global Tax Governance: What Is Wrong and How to Fix It (2016).
Those who write about the virtues and vices of the main creators of this framework usually disregard the World Bank (Bank), ${ }^{13}$ which in my opinion is not justified. I will therefore try to depict how and to what extent the Bank participates in the creation and implementation of such tax policy norms. Since these modes of participation of the Bank are based on its two related informal decisions to expand its activities into, respectively, domestic and international tax fields, I will explore these activities separately in two successive subsections. Subsequently, I will make an attempt to answer - equipped with the tools of legal doctrinal method ${ }^{14}$ - the following two questions: whether these decisions of the Bank were legal; and if so, what implications, if any, they have for the Bank's legitimacy. But before discussing all these matters, I will provide an overview of the Bank's most important features in the following section.

\section{Overview of the Bank}

\subsection{Introductory Remarks}

There are not very many intergovernmental organisations (IGOs) in the world that are as well known among people as the Bank. Yet their knowledge about this institution is usually vague, limited or erroneous because of the complexity of this IGO. Hence, an overview of the most important aspects of the Bank is presented in Subsections 2.2. to 2.5. These aspects will not only enable us to understand this IGO, but also serve as a basis for making an analysis in Section 4 to answer the research questions posed earlier.

\subsection{Structure and Mandates}

The Bank is one of the prominent global players in the field of development. In July 1944, the foundation for this multilaterally established IGO was laid down through the creation of the International Bank for Reconstruction and Development (IBRD) by representatives of 44 states at the Bretton Woods Conference. ${ }^{15}$ After the entry into force of its Articles of Agreement (Articles) in 1946, the IBRD officially started its work with 38 members. ${ }^{16}$ At that time, the majority of its members were located in Europe and the western hemisphere. ${ }^{17}$ The activities of the IBRD have been supplemented by the International Development Association

13. I refer herewith only to two lending institutions of the World Bank Group: the IDA and IBRD. See more about it in Section 2.1. of this article.

14. Conceptual analysis and moral reasoning

15. This conference, officially called the United Nations Monetary and Financial Conference, was held from 1 to 22 July 1944 in Bretton Woods, New Hampshire, the USA. See <http://worldbank.org/en/ about/archives/history/exhibits/bretton-woods-monetary-conference> (last visited 8 October 2017) and D. Kapur, J.P. Lewis \& R. Webb, The World Bank: Its First Half Century - Volume I: History (1997), at 9.

16. I.F.I. Shihata, The World Bank in a Changing World: Selected Essays and Lectures - Volume II (1995), at 2.

17. Nine of these states were from Asia and Africa, and the rest belonged to Europe and the western hemisphere. See id. 
(IDA) from $1960 .{ }^{18}$ Such a move was necessary since the IBRD was not allowed to provide 'concessional' lending (zero or very low interest credits) or grants from its capital. ${ }^{19}$ Both lending institutions operate under the Bank's name and have one and the same staff and project evaluation standards. ${ }^{20}$ Together with three other affiliates - the International Finance Corporation (1956), the Multilateral Investment Guarantee Agency (1988) and the International Centre for the Settlement of Investment Disputes (1966) - the Bank belongs to the World Bank Group (WBG).

According to Article I of its Articles, the IBRDs main mandate is 'to assist in the reconstruction and development of territories of members by facilitating the investment of capital for productive purposes'. In conformity with this mandate, the reconstruction of Europe after World War II initially formed the Bank's main mission, and the first non-project reconstruction loans were provided to Western European states. ${ }^{21}$ But shortly after its start, the bilateral United States' Marshall Plan replaced the Bank's work in those states. ${ }^{22}$ And as West Europe began to show clear signs of recovery, the Bank decided, in the late $1950 \mathrm{~s}$, to focus entirely on loans for development, shifting its activities to its developing members. ${ }^{23}$ For a long time, the Bank understood 'development' to mean 'having dams, bridges, and a (relatively) high GNP per capita'. ${ }^{24}$ Later, during the Presidency of Robert S. McNamara at the Bank, 'poverty alleviation' or 'the guarantee of a certain level of welfare to one's population' became another component of development. Since 2013, the Bank has had twin goals that should reach this development: 'eradicating the extreme poverty and boosting shared prosperity'. ${ }^{25}$ In addition to this mandate, the IBRDs Articles mention other purposes of this institution such as promotion of the long-range balanced growth of international trade and maintenance of equilibrium in balances of payments (emphasis added) by encouraging international investment for the development of the productive resources of members', ${ }^{26}$ promotion of 'private foreign investment by means of guarantees or participation in loans and other investments made by private investors 27 and supplementation of 'private investments by providing, on suitable conditions, finance for productive purposes out of its own

18. Art. I of Articles IDA (Effective 24 September 1960).

19. IDA 13, 'The IDA Deputies: An Historical Perspective', IDA (November 2001), at 1

20. F.J. Garcia, 'Justice, the Bretton Woods Institutions and the Problem of Inequality', Boston College Law School Faculty Papers, at 5 (2008).

21. The IBRD's first loans were provided to France, the Netherlands, Denmark and Luxembourg in 1947. See Kapur et al. (1997), above n. 15, at 10.

22. The official name of this bilateral assistance was the 'European Recovery Program'. It was announced in June 1947. Id

23. In 1948, the Bank provided its first loan for developmental purposes to Chile. See M. Finnemore, National Interests in International Society (1996), at 94

24. Id., at 92

25. World Bank Group, The World Bank Group A to Z (2016), at 67.

26. Art. I (iii) of Articles IBRD.

27. Art. I (ii) of Articles IBRD. capital, funds raised by it and its other resources' ${ }^{28}$ The IDA has a similar mandate, which is pursuant to its Articles 'to promote economic development, increase productivity and thus raise standards of living in the less-developed areas of the world included within the Association's membership, in particular by providing finance to meet their important developmental requirements on terms which are more flexible and bear less heavily on the balance of payments (emphasis added) than those of conventional loans, thereby furthering the developmental objectives of the International Bank for Reconstruction and Development (hereinafter called "the Bank") and supplementing its activities'. ${ }^{29}$ Although these mandates are extensively interpreted in practice by the Bank's management, the founding documents contain one explicit limitation to this possibility of interpretation: ${ }^{30}$ prohibition of political activity. ${ }^{31}$

\subsection{Organisation and Distribution of Voting Power}

The IBRD nowadays consists of 189 members or 'shareholders'. ${ }^{32}$ The membership of IBRD is, however, conditional on the membership of International Monetary Fund (IMF), which is open only for sovereign states. ${ }^{33}$ A state may acquire membership of the IDA if it has membership of the IBRD. ${ }^{34}$ At the moment the IDA has 173 members. ${ }^{35}$ These members together hold in principle the ultimate policy-making power on any issues that determines the course of the Bank. In practice, however, the members have a say only in matters concerning each of the institutions of the Bank through their (Alternate) Governors in the Boards of Governors (BoGs). ${ }^{36}$ The BoGs consist of one Governor and one Alternate Governor appointed by each member. ${ }^{37}$ The appointed (Alternate) Governors at the IBRD serve ex officio as the (Alternate) Governors of IDA, provided that states that they represent have membership of the IBRD. ${ }^{38}$ Any meetings of the BoGs are considered to be validly held when the majority of all Governors, who together represent two-thirds of the total voting power of that particular organisation, are present. ${ }^{39}$

As the BoGs usually convene once a year during the WBG and IMFs Annual Meeting in autumn, ${ }^{40}$ they

28. Id

29. Art. I of Articles IDA.

30. Shihata (1995), above n. 16, at 132-33

31. To be found in: Art. III (5[b]); Art. IV (10); and Art. V (5[c]) of the IBRD Articles. Also in Art. V (1[g]); Art. V (6); and Art. IV (5[c]) of the IDA Articles.

32. See <http://worldbank.org/en/about/leadership/members\#1> (last visited 9 October 2017).

33. Art. II (1) of Articles IBRD.

34. Art. II (1) of Articles IDA.

35. See <www.worldbank.org/en/about/leadership/members\#2> (last visited 9 October 2017).

36. Art. V (2[a]) of Articles IBRD and Art. VI (2[a]) of Articles IDA

37. Art. V (2[a]) of Articles IBRD and Art. VI (2[b]) of Articles IDA

38. Art. VI (2[b]) of Articles IDA

39. Art. V (4[f]) of Articles IBRD and Art. VI (2[f]) of Articles IDA.

40. The BoGs may convene on their own decision or on the BoD's request more than once a year. See Art. V (2[c]) of Articles IBRD and Art. VI (2[d]) of Articles IDA 
delegated their powers - with the exception of some ${ }^{41}$ to the Boards of Directors (BoDs). ${ }^{42}$ The BoDs are responsible for the Bank's general operations ${ }^{43}$ and consist of the Bank's President and 25 Executive Directors (EDs). ${ }^{44}$ According to Article V, Section 4, Subsection b Articles of IBRD, five of these EDs are appointed by the IBRDs 5 largest shareholders, ${ }^{45}$ whereas the rest are nominated out of several constituencies by other members. ${ }^{46}$ The IDAs BoDs is composed ex officio of each (Alternate) ED at the IBRDs BoDs, provided that they represent members having IBRD membership. ${ }^{47}$ The BoDs gather twice or more often per week. ${ }^{48}$ The quorum for these meetings is the majority of EDs representing at least one-half of the total voting power of this IGO. ${ }^{49}$ The EDs choose the Bank's President (President) for an extendable 5-year term, ${ }^{50}$ who chairs the meetings of the BoDs ${ }^{51}$ and leads, at the same time, the staff of the Bank. ${ }^{52}$ The staff under the responsibility of the President carries out the Bank's ordinary business. ${ }^{53}$ The President does not participate in the voting process during the meetings of the BoDs unless votes are equally divided, in which case he has a deciding vote. ${ }^{54}$

Matters within each of the institutions of the Bank are usually decided by a majority of votes cast. ${ }^{55}$ In certain situations specified in their founding documents, they may deviate from this general rule. However, the votes are allocated within each institution of the Bank unevenly owing to the difference in their membership. Moreover, the voting power in each institution is distributed unequally among the members because of the 'meighted voting system'. This system is the survival of the compromise that resulted from the Bretton Woods Conference. At this conference, the representatives discussed

41. The excluded powers differ per institution. See Art. $\vee(2[b]) ;$ Art. $\vee$ (4[b]); Art. VIII (a) of Articles IBRD and Art. VI (2[c]) of Articles IDA.

42. Art. V (4[a]) of Articles IBRD and Art. VI (4[a]) of Articles IDA.

43. Id.

44. Since 1 November 2010, the number of EDs has increased to 25. See <http://worldbank.org/en/about/leadership/directors> (last visited 9 October 2017)

45. These countries are the United States, France, the United Kingdom, Germany and Japan. See <http://siteresources.worldbank.org/ ESSDNETWORK/Resources/481106-1129303936381/1777397 -1129303967165/chapter1.html> (last visited 9 October 2017).

46. Saudi Arabia, the Russian Federation and China choose their own representatives. See S. Park, 'The World Bank - Plus Ca Change? Comment', in A.T. Weller and X. Yi-chong (eds.), The Politics of IOs: Views from Insiders (2015), at 87.

47. Art. VI (4[b]) of Articles IDA

48. See <http://siteresources.worldbank.org/ESSDNETWORK/Resources/ 481106-1129303936381/1777397-1129303967165/chapter1.html> (last visited 9 October 2017)

49. Art. V (4[f]) of Articles IBRD and Art. VI (4) of Articles IDA.

50. Section 13(c) By-Laws of IBRD (As amended through 26 September 1980).

51. Art. V (5[a]) of Articles IBRD and Art. VI (5[a]) of Articles IDA.

52. Art. $\vee(5[b])$ of Articles IBRD and Art. VI (5[b]) of Articles IDA.

53. Id.

54. Art. V (5[a]) of Articles IBRD and Art. V (5[a]) of Articles IDA.

55. Art. $\vee(10[b])$ of Articles IBRD and Art. VI (3[b]) of Articles IDA. This rule is nowadays considered to be of symbolic value as all matters within the two institutions of the Bank are decided on consensus. However, as Shihata noted, this rule is one of the factors that influence the current decision-making process within the Bank. See I.F.I. Shihata, The World Bank Legal Papers (2000), at 580. two approaches for the determination of voting power of each member state: one was based on the legal principle of the equality of states, and the other on the actual contributions or quotas. ${ }^{56}$ As a result, they agreed on a combination of both the approaches, consisting of basic votes and additional votes, depending on the number of subscribed shares in the capital stock of that institution. ${ }^{57}$ Nevertheless, these general approaches are elaborated differently in each of the Articles of the Bank's institutions. Whereas the basic votes of an IBRD member are determined by multiplying the aggregate sum of the voting power of all members by $5.55 \%,{ }^{58}$ the basic vote of an original IDA member is a fixed amount of $500 .{ }^{59}$ The same is true with regard to additional votes. An IBRD member may acquire one additional vote for each share of $\operatorname{stock}^{60}$ with a par value of $\$ 100,000,{ }^{61}$ while an original IDA member may acquire one additional vote for each $\$ 5,000$ of its initial subscription. ${ }^{62}$ It should, however, be noted that the above rules with regard to IDA's votes do not apply to IDA's members that could not be seen as the 'original member' of this institution in accordance with Article II, Section 1, Subsection a of its Articles. According to Article V, Section 3, Subsection a, Paragraph i of the IDAs Articles, the rules with regard to their voting rights are determined by the BoGs. During the IDAs third replenishment, the IDAs voting powers were realigned with relative contributions of its members without making a general adjustment in its Articles. ${ }^{63}$ The IBRD has also revised its distribution of voting power several times. However, these revisions led to adjustments of the IBRD's Articles. The last of such a revision took place in $2010^{64}$ but resulted only in a substantial increase in the voting powers of a few large economies, with a slight increase or even decrease in the voting powers of other developing members. ${ }^{65}$

\subsection{Finances}

The IBRD has traits similar to a banking institution. Its primary source of income is the international financial market, to which it issues bonds and other debt securities. ${ }^{66}$ These financial papers are bought by various par-

56. A. Buira, 'The Bretton Woods Institutions: Governance Without Legitimacy?', in A. Buira (ed.), Reforming the Governance of the IMF and the World Bank (2005) 2, at 9.

57. Id

58. Art. V (10 [a(i)]) of Articles IBRD. Before 2012, this basic vote was fixed and amounted to 250

59. Art. VI [3(a)] of Articles IDA.

60. Art. $\vee(3[a(i)])$ of Articles IBRD

61. Art. II (2[a]) of Articles IBRD

62. Art. VI (3[a]) of Articles IDA.

63. The BoGs had such a right based on Art VI (2 [c(ii)]) of the IDA's Articles. See IDA 13 (2001), above n. 19, at 3-4

64. Development Committee, 'World Bank Group Voice Reform: Enhancing Voice and Participation of Developing and Transition Countries in 2010 and Beyond', DC2010-0006, 19 April 2010; and World Bank Group, 2015 Shareholding Review: Report to Governors, 10 October 2015 Development Committee meeting, DC2015-0007, 28 September 2015.

65. See id. and <http://reuters.com/article/us-worldbank/china-gains-clout -in-world-bank-vote-shift-idUSTRE6301RQ20100425> (last visited: 9 October 2017).

66. The World Bank, A Guide to the World Bank (2011), at 67 
ties ranging from large public and private institutions to individuals. ${ }^{67}$ Since the debt papers are guaranteed by all members of this institution, they have a Triple-A credit rating, and as such, the IBRD pays a low market interest rate to its creditors. This minimum level of costs for funding enables this institution to set lower interest rates for its clients - with a small margin - than the market interest rates that these members would have received if they sold their own financial papers to the international financial market. ${ }^{68}$ In addition to this low interest rate, the IBRD offers its clients more flexible terms for its lending instruments than the international financial market. ${ }^{69}$

According to its Articles, the IBRD may also derive income from subscriptions to its capital. Article II, Section 5 in conjunction with Article II, Section 7, Paragraph $i$ of the Articles of IBRD stipulates that a country that joins the Bank pay $2 \%$ of its subscription to the IBRDs capital in gold or United States dollars. Whenever IBRD needs a funding for its operations, it may place a call on the $18 \%$ of the subscription, which could be paid to this institution in the currency of that member state. ${ }^{70}$ In case IBRD makes or facilitates loans specified in Article IV, Section 1, Subsection a, Paragraphs ii and iii Articles of IBRD, it may place a call on the remaining $80 \%$ of the subscription that could be made in gold or United States dollars or in any other currency of the member's choice. ${ }^{71}$ Until now, the IBRD has never invoked these provisions with regard to 'unpaid balance' in its Articles, since the Bank has always been able to pay its creditors back. ${ }^{72}$ Furthermore, its operating expenses have so far always been met from its operational income deriving from the small margin on its interest rates and interest income on its equity. ${ }^{73}$ The net amount that remains each year - after deduction of expenses - is used to fill up its reserves, and the amount that is left is transferred to the IDA. ${ }^{74}$ Furthermore, the IBRD administers its own and donor states' trust funds. ${ }^{75}$

The finances of the IDA differ greatly from those of the IBRD. Its main source of income consists of donations from its 52 donor members. ${ }^{76}$ To these donors belong not only 'old' wealthy economies - such as the United States or France - but also 'new' ones, like the Russian Federation, Brazil or Turkey. ${ }^{77}$ This funding is refilled by the donors every 3 years. ${ }^{78}$ In addition, the IDA derives its financial means from the contributions to its

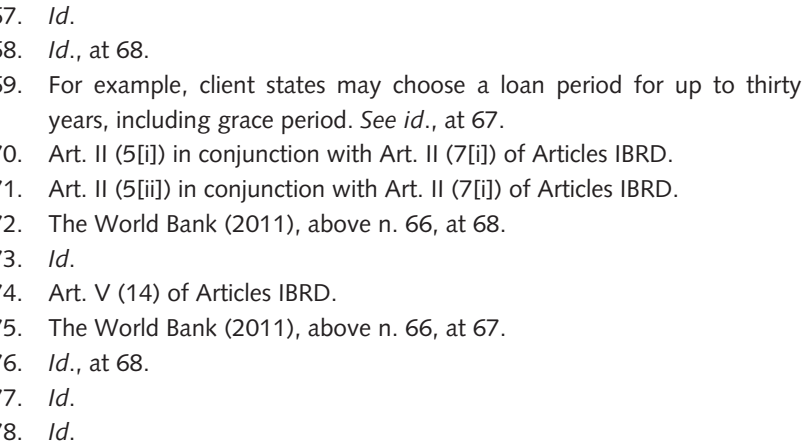

capital by its members, ${ }^{79}$ and through repayments of loan principal on its 20 - to 40 -year credits. ${ }^{80}$ Furthermore, the IDA receives funding from the $\mathrm{IBRD}^{81}$ and IFC. ${ }^{82}$

\subsection{Services}

At the moment, the Bank serves its 144 members as its clients. ${ }^{83}$ These services are provided in two different fields: finance and knowledge. ${ }^{84}$ The Bank's primary operations or activities take place in the financial field. However, it is not a commercial, but a cooperative institution that operates for the benefit of its members. ${ }^{85}$ Owing to that position and its mandate, the Bank's financial activities aim only at granting loans for developmental and reconstruction purposes to its members. The IBRD grants a loan to public institutions of its clients for development projects at 'preferential' terms or rates close to commercial rates. ${ }^{86}$ Private institutions may also borrow from IBRD funds, provided that their borrowing is guaranteed by a member. On the other hand, IDA's credits could be borrowed by low-income members on so-called 'concessional' terms or very low and sometimes zero-interest rates. ${ }^{87}$ The IDA also provides grants to its clients suffering from debt distress. ${ }^{88}$ Besides its credits and grants, IDA helps its clients with the Heavily Indebted Poor Countries (HIPC) Initiative and the Multilateral Debt Relief Initiative (MDRI). ${ }^{89}$

The major eligibility test to borrow from IDA or IBRD resources is determined by two factors: (a) relative poverty; or (b) lack of creditmorthiness for market-based loans. Relative poverty is defined through calculation of per capita gross national income $(\mathrm{GNI})^{90}$ based on the Bank's Atlas method. ${ }^{91}$ If the GNI of that member is below a certain level, which is determined each year, then that member is eligible to borrow from IDA funds. ${ }^{92}$ Some members, whose GNI lies above the threshold but that do not meet the requirement for creditworthiness are also allowed to borrow from this institution. ${ }^{93}$ Some IDA eligible members, which are creditworthy, may also borrow from certain IBRD funds. ${ }^{94}$ These members are usually called blend bor-

79. Art. II (2) of Articles IDA

80. The World Bank (2011), above n. 66, at 68

81. Art. V (14) of Articles IBRD.

82. The World Bank (2011), above n. 66, at 68

83. See <https://datahelpdesk.worldbank.org/knowledgebase/articles/ 906519-world-bank-country-and-lending-groups> (last visited 9 October 2017)

84. World Bank Group (2016), above n. 25, at 141.

85. The World Bank (2011), above n. 66, at 68

86. Garcia, above n. 20

87. See <https://ida.worldbank.org/about/what-ida> (last visited 9 October 2017).

88. Id.

89. Id

90. Formerly known as GNP.

91. See <https://datahelpdesk.worldbank.org/knowledgebase/articles/ 378832-what-is-the-world-bank-atlas-method> (last visited 9 October 2017).

92. $\$ 1,165$ in fiscal year 2018. See <http://ida.worldbank.org/about/ borrowing-countries> (last visited 9 October 2017).

93. Id

94. Id. 
rowers. ${ }^{95}$ At the moment, 69 are IBRD, 59 are IDA and the remaining 16 members are blend borrowers. ${ }^{96}$

The Bank may provide, in accordance with its Articles, its financing only for 'specific projects', except in 'special circumstances'. ${ }^{97}$ On the basis of these provisions, the Bank has now three main financing instruments. The most frequently used and oldest lending instrument $^{98}$ is Investment Project Financing (IPF), ${ }^{99}$ which was formerly known as 'investment loans'100 and 'investment guarantees'. As of fiscal year 2015, around $70 \%$ of the Bank's loans consisted of this type of loan. ${ }^{101}$ The operations financed with this lending instrument have a duration of 5 to 10 years. ${ }^{102}$ The aim of this lending instrument is to provide financial means and related operational support on the basis of various projects such as goods, works and services within the framework of economic and social development. ${ }^{103}$ The second largest financing instrument is Development Policy Financing (DPF), ${ }^{104}$ which takes a share of $29 \% .{ }^{105}$ The Bank replaced with this single and quick-disbursing lending instrument all its policy-based or adjustment loans in August 2004. ${ }^{106}$ It is used to restore the member's balance of payments disequilibrium, and supports government policy and institutional reforms such as tax reform. ${ }^{107}$ The DPF attaches to the IBRD's loans, IDA's credits and grants, as well as IBRD and IDA's guarantees, a condition or 'conditionality' encompassing a policy reform and actions that should be implemented by its borrowers. ${ }^{108}$ The last and - at the time moment the least used lending instrument is Program-forResults Financing (PfR). It was created in 2012 and

95. Id.

96. Id. See also <https://datahelpdesk.worldbank.org/knowledgebase/ articles/906519-world-bank-country-and-lending-groups> (last visited 31 October 2017).

97. Art. II (4[vii]) IBRD Articles and Art. V (1[b]) IDA Articles.

98. World Bank, 2015 Development Policy Financing Retrospective (2014), at 1.

99. On 25 October 2012, Bank's BoDs approved a set of reforms that were aimed at simplifying the project loans. These reforms took effect from 8 April 2013. The new policy replaced many policies and procedures on project-based loans with a single policy called OP/BP 8.60 on Investment Project Financing.

100. These investment loans included Specific Investment Loan, Sector Investment and Maintenance Loan, Adaptable Program Loan Learning and Innovation Loan, Technical Assistance Loan, Financial Intermediary Loan and Emergency Recovery Loans. See World Bank - Operations Policy and Country Services, 'Lending Instruments: Resources for Development Impact', (2001), at 5.

101. World Bank (2014), above n. 98, at 1.

102. World Bank Group (2016), above n. 25, at 52.

103. Id. See also OP 10.00

104. DPF is governed by the operational policy approved by the Bank's EDs in August 2004 (OP 8.60)

105. World Bank (2014), above n. 98, at 1.

106. This change took place through OP 8.60. See Legal Vice Presidency World Bank, 'Review of World Bank Conditionality: Legal Aspects of Conditionality in Policy-Based Lending', (2005), at 3.

107. The World Bank (2011), above n. 66, at 76.

108. Section III (4) of OP 8.60 of the Bank.

109. World Bank (2014), above n. 98, at 1 accounts for $5 \% .{ }^{109}$ It links 'disbursements directly to the delivery of defined results'. ${ }^{110}$

In addition to its lending operations, the Bank carries out analytical and research work activities. These activities are performed usually in combination with its lending operations and sometimes on a stand-alone basis. In the analytical field, the Bank has an instrument that is called Advisory Services and Analytics (ASA). ${ }^{111}$ By using this instrument it provides its clients 'with customized expertise and analytics, either as stand-alone services or as a complement to financial support programs'. ${ }^{112}$ The ASA encompass Economic Sector Work (ESW), Non-Lending Technical Assistance (TA) and impact evaluation and training. ${ }^{113}$ Out of these instruments the ESW is targeted to 'influence policy choices and programs' through diagnostic and analytical reports. ${ }^{114}$ It can be divided into three sub-activities, namely core diagnostic work (CDW), sector and thematic studies (STS) and other ESW. The CDW is performed prior to and in support of its lending programmes. ${ }^{115}$ The STS, as well as the other ESW, are aimed at influencing programmes and policies in client countries. Moreover, the reports concluding these studies contain officially endorsed recommendations by the Bank and express the formal position held by the Bank units that performed the study. ${ }^{116}$ On the other hand, the Non-Lending TA is utilised for 'building capacities and strengthening institutions through events and reports'. ${ }^{117}$ The Bank funds its stand-alone non-lending operations with either its own financial means or donorprovided trust funds and resources or funds provided by its clients themselves. The research work activities are carried out by the Bank itself or performed on commission by other parties.

All these loans and assistance in the field of knowledge are usually provided within the framework of comprehensive lending programmes laid down in its Country Assistance Strategy paper. This paper is the result of a periodic negotiation between the Bank and the borrowing member state and contains the main points of the Bank's assistance to its clients, reflecting local circumstances and needs.

\subsection{Concluding Remarks}

The Bank is a multilaterally established financial IGO active in the developmental field. At its creation, it was largely a Western organisation both in its operational field and in membership, but today its operations focus entirely on developing states, and more than the majority of its members belong to these states. Nevertheless,

110. IMF, OECD, UN and WBG, 'Enhancing the Effectiveness of External Support in Building Tax Capacity in Developing Countries', (July 2016), at 44 .

111. Id.

112. Id.

113. Id.

114. $I d$.

115. See <https://openknowledge.worldbank.org/handle/10986/6> (last visited 9 October 2017)

116. Id.

117. IMF et al. (July 2016), above n. 110, at 44. 
the decision-making power within this IGO remained, owing to its meighted voting system, in the hands of its wealthy shareholders located in the West - with the notable exception of some high-income developing states that are politically and economically important.

\section{On the Bank's Activities in the Tax Field}

\subsection{Introductory Remarks}

In Section 2.5, I gave an overview of the services that the Bank provides to its client member states. This section aims to elaborate on that matter by focusing on the tax-related activities of the Bank. As these activities derive from two related informal decisions of the Bank to expand its activities into the domestic and international tax fields, I will depict these activities separately in the following two subsections.

\subsection{Activities after Expansion into the Domestic Tax Field}

Domestic tax issues of its developing members became a concern of the Bank from the 1970 s onwards. ${ }^{118}$ During that incipient period, the Bank's tax related advice mostly focused ona particular sector in its client's economy. ${ }^{119}$ A little attention - if any - was paid to the general tax structure. ${ }^{120}$ Whenever it formed a part of the advice it was only about raising the taxes. ${ }^{121}$ The tax administration seemed to be an issue that was not worth considering. ${ }^{122}$

In the late $1970 \mathrm{~s}$, the Bank's many developing members were hit by severe balance of payments problems. ${ }^{123}$ Since the efforts of the formal legal transplantations under the Law and Development movement had not resulted in the desired outcomes, ${ }^{124}$ the Bank decided to pursue a new strategy based on a neoliberal economic model. ${ }^{125}$ The conviction for this macroeconomic strategy came from the Bank's study conducted in SubSaharan Africa that presented bad domestic policies to be the cause of failed efforts to yield economic development and advised replacement of these policies with market-oriented ones as a strategy that would lead to more economic growth. ${ }^{126}$ So from 1980, ${ }^{127}$ the Bank began - based on the 'special circumstances' provision in Article I, Section iii of IBRD's Articles and Article I

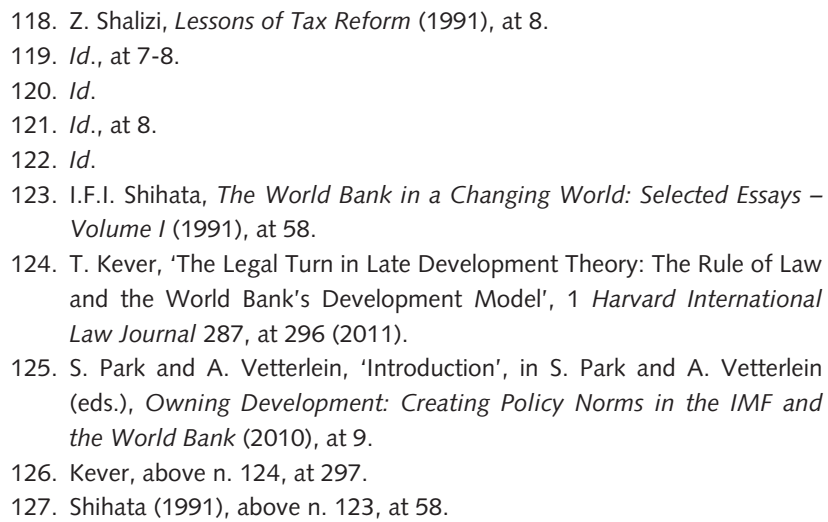

of IDA's Articles - to provide non-project loans. ${ }^{128}$ These loans were accompanied by conditions or 'conditionalities' that required the borrower to implement 'a program of reforms and actions'. ${ }^{129}$ These reforms and actions had to be in line with the aforementioned neoliberal economic policies, ${ }^{130}$ which are usually mistakenly called 'Washington Consensus' policies. ${ }^{131}$

The introduction of this neoliberal strategy was accompanied by the expansion and intensification of tax advisory and analytical activities in the existing tax work field. ${ }^{132}$ Nevertheless, the Bank organised and discussed general tax policy issues during its meetings with clients based on the analysis and recommendations given by other IGOs, ${ }^{133}$ such as the IMF or the United States Agency for International Development. Moreover, the Bank took part in some tax missions that were organised by the IMF to review the existing conditions and devise new policies. In the mid-1980s, the Bank's working method changed as a result of a significant increase in requests from its clients for TA and policy advice on tax issues. $^{134}$ Empowered by the initial activities and requests from its clients, the Bank embarked on its own mission to reform the tax systems of its developing members. For that purpose, it produced 'detailed reports and recommendations' and independently carried out negotiations with its clients to reflect these recommendations in its adjustment lending programmes. ${ }^{135}$ However, as a result of several incidents and the Asian financial crisis in 1997, it began to closely coordinate its policy-based loans with the IMF. ${ }^{136}$

In the beginning, only tax policy issues were reflected in the Bank's adjustment loans with tax-related conditionality. The conditionality in these loans was primarily directed at 'generating revenue to stabilize the economy'. ${ }^{137}$ Later on, it began to include 'broader policies of encouraging more efficient allocation in private production and investment' and 'greater attention to equity'. ${ }^{138}$ Notwithstanding this shift in its focus, the tax policy conditions were always in line with 'the prevailing best practices' of that period. ${ }^{139}$ Gradually, the Bank realised that the implementation of its tax policy reforms also depended on 'the implementation capacity of governments and their commitments to reform' in developing members. ${ }^{140}$ As a result, the Bank's conditionality was

128. Id., at 63-4 and Legal Vice Presidency - World Bank (2005), above $\mathrm{n}$. 106 , at iv.

129. Legal Vice Presidency - World Bank (2005), above n. 106, at iv.

130. Shihata (1991), above n. 123,63-4. Also see Park and Vetterlein, above n. 125 , at 10 (fn. 3)

131. J. Williamson, 'What Should the World Bank Think about the Washington Consensus?', 2 The World Bank Research Observer 251, at 251 (2000)

132. Shalizi (1991), above n. 118, at 8.

133. Id.

134. Id

135. Id.

136. The Secretary of the U.S. Treasury, 'IMF and World Bank collaboration and IMF Accountability', (2009), at 2-3.

137. Shalizi (1991), above n. 118, at 9.

138. Id., at 9-10.

139. Id., at 8 .

140. Shihata (1991), above n. 123, at 59. 
expanded to include institutional changes in macroeconomic and financial management, sectoral restructuring and policy reforms, enhancement of public sector efficiency and constraints in public sector management'. ${ }^{141}$ In the tax field, it meant the implementation of tax administration reforms, ${ }^{142}$ which concerned organisational and functional reforms. ${ }^{143}$ From 1987, tax administration reforms were increased in volume and with that became a significant part of the Bank's work in the tax field. ${ }^{144}$ Nevertheless, as Zmarak Shalizi noted, the overall involvement of the Bank in reforming tax systems of its developing members was always restricted to partial reform programmes and did not include allembracing major tax policy and tax administration reforms. $^{145}$

\subsection{Activities after Expansion into the International Tax Field}

The Bank has focused until recently only on domestic tax issues of its developing members. However, the outbreak of the 2008 global financial and economic crisis reduced domestic public revenues even in high-income developed economies. This fact, combined with the subsequent exposure of the extensive aggressive tax planning practices for MNEs and HNWIs, enhanced the G20's attention on public resources. Starting with its high-level meeting in 2010, the G20 has consequently issued several requests to four major IGOs - the Organisation for Economic Co-operation and Development (OECD), IMF, WBG and United Nations (UN) active inter alia in the field of taxation. The first of these requests was made during the G20's Seoul Summit. ${ }^{146}$ As a follow-up to this request, the four IGOs brought out a report in 2011 that threw light on ongoing work of all four IGOs that aim at tax capacity building in developing states. ${ }^{147}$ The next request from the G20 Development Working Group came in the first half of 2015. In the build-up to the 10th meeting of the G20 heads of government and heads of state, it requested the four IGOs to investigate options for low-income countries' effective and efficient use of tax incentives for investment, which is considered to be one of the main causes of tax competition in developing states. ${ }^{148}$ Again, the four IGOs responded to this request with a presentation of their joint report, ${ }^{149}$ which was discussed during the

141. $/ d$.

142. J. Datta-Mitra, Fiscal Management in Adjustment Lending: A World Bank Operations Evaluation Study (1997), at 72.

143. Shalizi (1991), above n. 118, at 10

144. Datta-Mitra (1997), above n. 142, at 72.

145. Shalizi (1991), above n. 118, at 45.

146. IMF, OECD, UN and World Bank, 'Supporting the Development of More Effective Tax Systems: A Report to the G-20 Development Working Group', (2011), at 10

147. Id.

148. IMF, OECD, UN, and World Bank, 'Options for Low Income Countries' Effective and Efficient Use of Tax Incentives for Investment', (2015), at 6.

149. The report has a title 'Options for Low Income Countries' Effective and Efficient Use of Tax Incentives for Investment.' It was presented to the G20 Development Working Group in September 2015. See id., at 2.
G20 Antalya summit. ${ }^{150}$ This request was, however, not the last one, and several other requests followed afterwards.

In the meantime, in preparation for the third International Conference on Financing for Development, the six major international and regional development banks, along with the IMF, presented a joint discussion note to the 18 April 2015 Development Committee meeting of the Bank and IMF. ${ }^{151}$ This note, called 'From Billions to Trillions: Transforming Development Finance', offered a new approach to financing for development, which emphasised the need for strengthening domestic public resources of developing states and the role that the multilateral development banks, as well as the IMF, should play in this process. ${ }^{152}$ This approach was subsequently adopted in the 'Addis Ababa Action Agenda'. 153 Shortly after, during the UN Sustainable Development Summit, held in New York from 25 to 27 September 2015, the international community adopted a declaration with a new set of Sustainable Development Goals, ${ }^{154}$ which replaced Millennium Development Goals. ${ }^{155}$ In paragraph 41 of this declaration, the UN General Assembly recognised that 'each country has primary responsibility for its own economic and social development' and that 'implementation of the Goals and targets' will need inter alia 'the mobilization of financial resources as well as capacity-building'. Furthermore, it stated therein that public finances will play a pivotal role in that process. This and other statements of the declaration show that the Addis Ababa Action Agenda forms an integral part of this declaration. As a result, strengthening tax systems - both tax policy and tax administration - became one of the main global development priorities. ${ }^{156}$

In light of these developments on the international political arena, it became necessary for the Bank to make international tax issues another component of its work. Accordingly, a Global Tax Team was created within the Bank's Governance Global Practice as a departmental unit, which is responsible for coordination of the Bank's international tax-related work, in the first quarter of 2016. ${ }^{157}$ Its main mandate, according to the information placed on the Bank's website, is the design of 'struc-

150. The 10th annual meeting of the G20 heads of government and heads of state, organized in Antalya, Turkey, from 15 to 16 November 2015.

151. Joint Ministerial Committee of the Boards of Governors of the Bank and the IMF on the Transfer of Real Resources.

152. See <http://www5.worldbank.org/mdgs/post2015.html> (last visited 9 October 2017).

153. The 'Addis Ababa Action Agenda' of the Third International Conference on Financing for Development, adopted by the General Assembly on 27 July 2015 (resolution 69/313, annex).

154. This declaration is titled 'Transforming our world: the 2030 Agenda for Sustainable Development' and adopted by the General Assembly on 25 September 2015 (resolution A/RES/70/1)

155. These goals are to be found in the 'UN Millennium Declaration', which was adopted by the General Assembly on 8 September 2000 (resolution $55 / 2$ ).

156. IMF, OECD, UN and World Bank, 'Concept Note: The Platform for Collaboration on Tax', (April 2016), at 3.

157. See <www.worldbank.org/en/topic/governance/overview\#2> (last visited 9 October 2017). 
tured guidance on tax policy and administration reform and to ensure that the global discussion around international tax issues acknowledges the circumstances of developing countries and serves to advance the Bank Group's twin goals'. ${ }^{158}$ This meant in practice that the Bank supports its clients with the design and implementation of instruments and administrative procedures to address key sources of base erosion, which includes transfer mispricing, tax treaty application issues, detecting and adjudicating aggressive tax planning structures and other methods of profit shifting, and tax transparency through exchange of information. ${ }^{159}$

In addition to the creation of the Global Tax Team, the Bank decided, together with its partner IGOs, to enhance its cooperation in the tax field. Consequently, they created a Platform for Collaboration on Tax (Platform) in April 2016. ${ }^{160}$ This Platform, however, did not create a new formal IGO as its members stay independent from each other in carrying out their own mandated activities. ${ }^{161}$ As its founding document 'Concept Note' stated, the Platform was created owing to a rise of common challenges that derive from the increased linkages between economies and progress in reform'. ${ }^{162}$ Furthermore, it noted that the main purpose of this Platform is to intensify tax-related cooperation between these main IGOs in order to 'better support governments in addressing the tax challenges they face'. ${ }^{163}$ To these supporting activities belong the issuance of joint outputs on both domestic and international tax issues, the exchange information on their respective operational and knowledge activities, ${ }^{164}$ and the coordination of their activities that should link the standard setting to capacity building and TA. ${ }^{165}$ In reality, the last task implied implementation of the results of the OECD/ G-20 Base Erosion and Profit Shifting project ${ }^{166}$ and effectuation of the Global Standard for Transparency and Effective Exchange of Information ${ }^{167}$ in developing members. ${ }^{168}$ Within the framework of this informal network, the committed IGOs also aim to continue on a regular basis the already existing discussions on 'the design and implementation of standards for international tax matters' ${ }^{169}$ Moreover, they wish to organise highlevel as well as technical-level meetings to discuss tax issues ${ }^{170}$ and to support developing states with their par-

158. Id.

159. IMF et al. (July 2016), n. 110, at 45.

160. IMF et al. (April 2016), above n. 156, at 3.

161. Id.

162. Id.

163. Id., at 5 .

164. IMF Press Release No. 16/176, 19 April 2016.

165. IMF et al. (April 2016), above n. 156, at 5.

166. This project aims to counter tax avoidance strategies of MNEs.

167. The standard was developed within the framework of the Global Forum on Transparency and Exchange of Information for Tax Purposes.

168. IMF et al. (April 2016), above n. 156, at 8-9.

169. Id., at 3 .

170. Id., at 6 and 10 ticipation in the future global standard setting process. $^{171}$

After this second expansion, the Bank's work in the tax field is now mostly aimed at building the capacity of the tax systems of its clients. ${ }^{172}$ This capacity building work is focused on both domestic tax related issues (domestic tax policy and administration) and international tax related issues. ${ }^{173}$ In relation to domestic tax policy, various tax reform programmes have been devised so far. ${ }^{174}$ These reforms range from comprehensive reforms to reforms restricted to a certain part of the tax system, such as tax incentives. The reforms are subsequently implemented and sustained in practice through domestic tax legislation, judicial work and operations of the tax administration. Whereas tax legislation forms a part of the overall tax reform programmes, judicial reforms have been receiving due attention from the Bank as a part of its rule of law programmes. ${ }^{175}$ In contrast to them, tax administration reforms have always formed a distinct part of the Bank's overall work in the tax field. In the field of international taxation, the Bank assist developing members with the design and implementation of instruments and administrative procedures for effectuation of international standards. ${ }^{176}$

In order to carry out these tax-related activities, the Bank has been using various lending and non-lending instruments that are available to it. These instruments are combined in such a way that it provides support to client states 'from diagnosis to analysis of causes ad solutions of tax issues, design of a program of capacity building, implementation, and, finally, evaluation.' ${ }^{\text {177 }}$ The most relevant ones among them are now, without doubt, the Bank's lending instruments: the IPF, DPF and PfR. ${ }^{178}$ The IPF is used for 'building physical and social infrastructure, such as Information Management Information Systems and business process re-engineering for tax administrations', whereas the DPF is employed 'for a program of policy and institutional actions, such as changes in tax laws and arrangements for providing tax incentives to foreign investors'. ${ }^{179}$ Compared with IPF and DPF, the PfR is used to achieve predefined results in taxation. ${ }^{180}$ In addition to these main lending instruments, the Bank conducts preparatory studies about a tax system prior to carrying out its tax reforms known as ESW, which are usually funded by the Bank's own budget. Furthermore, it carries out various tax-related researches and assists in drafting of tax legislation. These activities are mostly financed by

171. Id., at 8. Until today, no steps have been undertaken on the international level that give a true participating right to developing states in such process, so the intention of this network to support them in this process is doubtful.

172. IMF et al. (July 2016), n. 110, at 44.

173. Id., at $44-45$.

174. Id., at 45 .

175. Shihata (1995), above n. 16, at 127-32

176. IMF et al. (July 2016), n. 110, at 45.

177. Id., at 44 .

178. See for these lending instruments in Section 2.5 .

179. IMF et al. (July 2016), n. 110, at 44.

180. Id. 
the Bank's Institutional Development Fund and other ad hoc funds. ${ }^{181}$

\subsection{Concluding Remarks}

As early as the 1970 s, the Bank made an informal decision to expand its activities into the domestic tax field of its developing members. Initially, the Bank's work was focused on non-lending tax-related activities, which encompassed analytical and advisory work. But gradually, the scope of the Bank's work expanded to include tax policy and tax administration reforms. These reforms have been carried out first through the Bank's adjustment loans and later through the DPF. After the outbreak of the global economic and financial crisis in 2008, the Bank had to shift its attention to international tax issues owing to enhanced attention of the G20 on public revenue. As a result, the Bank participates nowadays not only in the creation of tax policy norms on the global level, but also in the implementation of these norms in its developing members.

\section{Examinations}

\subsection{Introductory Remarks}

This section aims to give an answer to each of the two questions posed in the introduction of this article. The first question is about the legality of the Bank's informal decisions to expand into the domestic and international tax fields. This issue will be addressed in Section 4.2. The second question concerns the possible implications of these two decisions for the Bank's legitimacy. That issue will be explored in Section 4.3.

\subsection{On Legality of the Decisions to Expand}

The Bank's mandates are laid down in Article I of both IBRD and IDA's Articles. Neither this long list of mandates nor any other parts of the Bank's founding documents contain any explicit reference to taxation. Yet this lack of black letters cannot immediately be seen as a legal impediment for expansion of the Bank's activities into the tax field. For the Bank's Articles are intentionally defined as broadly and vaguely as possible, similar to the case with any other mandates of any IGOs. Moreover, ambiguity is an inherent quality of every language. ${ }^{182}$ As a result of that the meaning of a word or text is rarely clear and always contingent on a context. This nature of a language, therefore, makes interpretation a necessary part of a lawyer's work. The tools or methods of interpretation at the disposal of lawyers are, however, limited in number. Besides that it cannot be applied in an arbitrary way. For that purpose, Articles 31 and 32 of the Vienna Convention on the Law of Treaties ${ }^{183}$ contain a set of rules that determine how

181. Shihata (1995), above n. 16, at 134-35.

182. J.E. Alvarez, 'Constitutional Interpretation in international organizations', in J. Coicaud and V. Heiskanen (eds.), The Legitimacy of International Organizations (2001) 104, at 116.

183. UN DOC.A/CONF. 39/11/Add.2. these interpretation methods should be applied in relation to treaties or agreements between states.

According to Article 31(1) of this convention, 'A treaty shall be interpreted in good faith in accordance with the ordinary meaning (emphasis added) to be given to the terms of the treaty in their context and in the light of its object and purpose.' Under the context mentioned in this provision, the convention subsumes not only preamble, text and annexes of that particular treaty, but also other related agreements and instruments to that treaty. ${ }^{184}$ In addition to the context, the convention implors to pay attention to: '(a) any subsequent agreement between the parties regarding the interpretation of the treaty or the application of its provisions; (c) any subsequent practice in the application of the treaty which establishes the agreement of the parties regarding its interpretation; or (c) any relevant rules of international law application in the relations between the parties'. ${ }^{185}$ Furthermore, an interpreter should respect a 'special meaning' of a certain term provided that it is demonstrated by the intention of the parties concerned. ${ }^{186}$ These general rules of interpretation could be, nonetheless, supplemented by other methods of interpretation in order: (1) to validate the meaning determined through the application of the general rules of interpretation; or (2) to determine a different meaning in case the meaning already found through the application of the general rules of interpretation is 'ambiguous' or 'absurd', or leads to a result 'manifestly absurd' or 'unreasonable'. 187

These rules of interpretation of a treaty lead to many uncertainties in practice. ${ }^{188}$ The only clear rule that follows from them is the rule of hierarchy that says that a 'textual' or linguistic interpretation method ${ }^{189}$ should be preferred over other interpretation methods. ${ }^{190}$ For the textual interpretation, however, we need to pay due attention to the context of the terms used ('contextual' or linguistic interpretation in the context involved) $)^{191}$ and also take into account the object and purpose of the treaty or organisation ('teleological' or purposive interpretation). ${ }^{192}$ Moreover, the subsequent practice - in the case of an organisation it means especially the exercise of 'implied powers ${ }^{\prime 193}$ - should play a role during this endeavour. The 'subjective' or intentionist interpretation method ${ }^{194}$ could also be applied - but only as a last 'resort'195 - when the foregoing methods do not lead to reasonable results or when a special meaning of the

184. Art. 31(2) of Vienna Convention on the Law of Treaties.

185. Art. 31(3) of Vienna Convention on the Law of Treaties.

186. Art. 31(4) of Vienna Convention on the Law of Treaties.

187. Art. 32 of the Vienna Convention on the Law of Treaties.

188. Alvarez (2001), above n. 182, at 116.

189. I.F.I. Shihata, The World Bank in a Changing World - Volume III (2000), at 6.

190. Alvarez (2001), above n. 182, at 116

191. Shihata (2000), above n. 189 , at 6 .

192. Id.

193. Id., at 15. For implied powers see n. 238.

194. Id., 6.

195. Alvarez (2001), above n. 182, at 116 and Shihata (2000), above n. 189 , at 15 . 
words was intended. As Jose E. Alvarez noted, the wording of the provisions contains further vague terms such as 'in good faith' and 'ordinary meaning', which ask in their turn for the application of 'canons of interpretation' that leave substantial discretionary space to the interpreter. ${ }^{196}$ This leads to the conclusion that any endeavours of interpretation will depend much on the interpreter who is authorised to do that work. ${ }^{197}$ But who is the authoritative interpreter in the case of the Bank's articles?

According to the Bank's founding documents, the Bank's EDs are authorised to decide on issues concerning disagreements with regard to interpretation of the Bank's articles. ${ }^{198}$ This decision can be appealed before the BoGs, which is designated as a competent authority to review the decisions of the EDs. ${ }^{199}$ As is clear from these provisions of the Bank's Articles, these organs appear on stage only in exceptional situations when disagreements arise regarding the interpretation of the articles. This suggests that someone other than these two organs takes the initial decision for interpretation in the day-to-day practice of the Bank. According to the San Francisco decision given with regard to the interpretation of the UN Charter, issues of interpretation are left to each institutional organ of the United Nations. ${ }^{200}$ This decision has attained widespread acceptance and is considered to be applicable to other IGOs. ${ }^{201}$ Consequently, each element of an organisation, including its members, is eligible for that task. ${ }^{202}$ Since the question operational field of the Bank, the Bank's internal organs that decide on or approve its policies and operations would likely be the designated instances to make such interpretations. And in the case of the Bank, these organs that decide on or approve the Bank's policies and operations are the BoDs and ultimately the BoGs. ${ }^{203}$ These are one and the same bodies entitled to interpret the Bank's Articles or review the Bank's policies and operations. In light of these rules, it is understandable that the Bank's EDs nowadays incorporate their interpretations in their policy papers. ${ }^{204}$ Although a member state has, in principle, the right to contest initial interpretation, the conflation of two roles - determination of policies and operations in line with the Articles and interpretation of those articles - makes in advance the possibility to contest such an initial interpretation need-

196. Alvarez (2001), above n. 182, at 116 .

197. Id.

198. Art. IX (a) of Articles IBRD and Art. X (a) of Articles IDA.

199. Art. IX (b) of Articles IBRD and Art. $X$ (b) of Articles IDA. Up to the present moment, none of the Bank's members has done such a request for review. See Shihata (2000), above n. 189, at 16.

200. During the drafting process of the UN Charter, the drafters of this instrument assigned a subcommittee to decide on the issue of interpretation. This subcommittee produced a report that was adopted by both the Committee on Legal Problems and Conference. See Alvarez (2001), above n. 182, at 111-2.

201. Id., at 112 .

202. Id.

203. Art. V (4[a]) IBRD Articles and art. VI (4[a]) IDA Articles.

204. Shihata (2000), above n. 189, at 6 and Shihata (1991), above n. 123, at 68. of expansion of the Bank's activities belongs to the

less. Even if we can imagine that such a possibility exists, then, as Alvarez noted, 'members may not contest institutional practices' owing to 'lack of transparency, absence of financial or other resources to mount a challenge, or simply fear of giving offence to powerful members or organs'. ${ }^{205}$ Moreover, the resistance of some members might be seen in practice as invalid since there is no agreement as to what should be reckoned as 'opposition' and whether or not it was or should be seen as timely filed. ${ }^{206}$ But we know that as long as the initial interpretations are not contested by a member state, they are presumed to be 'legal'. For an 'unchallenged institutional practice' resembles tacit consent ${ }^{207}$ and even constitutes 'precedents' for future reference. ${ }^{208}$ In these circumstances, the only comfort could be, therefore, found in the involvement of the legal opinion issued by the Bank's General Counsel in this BoDs' interpretation process, which became a practice since the establishment of the IBRD. ${ }^{209}$ Thanks to this informal process, the BoDs' interpretations reflected in their policy papers contain to a certain extent the legal rationale that confines totally arbitrary interpretations. ${ }^{210}$

As was mentioned earlier in this article, the IBRD's main mandate is to assist in reconstruction and development of its members by facilitating and financing investment for productive purposes. In addition to this, the IBRD pursues other goals such as promotion of longrange balanced growth of international trade and maintenance of equilibrium in the balance of payments by encouraging international investment for the development of productive resources of members. According to the Bank's former Senior Vice President and General Counselor, Ibrahim Shihata, these 'purposes' of the IBRD define two 'statutory roles' of the Bank: 'that of a facilitator and promoter of investment of capital, especially private foreign investment, for reconstruction and productive purposes in member states'; and (b) 'that of a financier, i.e. a guarantor of/or a participant in "loans and other investments" made by private foreign investors and a direct lender of funds to finance or facilitate productive purposes on suitable conditions "when private capital is not available on reasonable terms." 211 As Shihata further noted, the first of these two roles has been empowering the Bank 'to address the conditions that attract investment and the enabling environment needed for economic growth and development'. ${ }^{212}$ This role was the fertile ground for many expansions of the Bank's activities. $^{213}$ It therefore seems to me plausible to conclude from it that the two successive expansions into the tax field were also rooted in this role. Even more notably, tax measures are related to increase in private for-

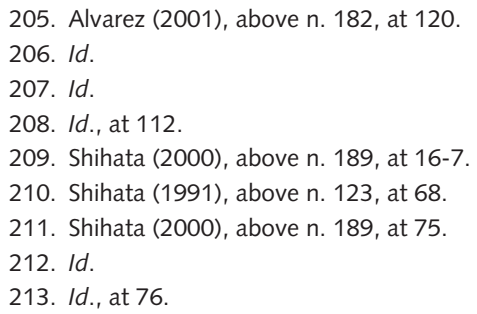


eign investment owing to their ability to affect investment decisions by creating an enabling environment that promotes investments. Moreover, taxes are needed for financing public expenditures. Under these public expenditures, one might also include public investments for productive purposes. Although the Bank aims primarily at promotion of private investments, its mandate does not prevent it from promoting public investments for productive purposes as well. So paying attention to taxation can lead to an increase in both private and public investments for productive purposes. In this way, tax issues fall clearly under the mandate of the Bank. The same is true with regard to the IDA's mandates, as taxation is one of the possible measures that indirectly or directly could promote economic development, increase productivity and thus raise standards of living in the less developed areas of the world.

Nonetheless, the Bank's founding documents contain three other provisions, which make the above conclusion doubtful. These provisions preclude the Bank undertaking any activities that fall within the prohibited political intervention. They are applicable to all decisions of the Bank ${ }^{214}$ and could be found in Article III, Section 5 (b); Article IV, Section 10; and Article V, Section 5 (c) of the IBRD Articles and Article V, Section 1 (g); Article V, Section 6; and Article VI, Section 5 (c) of the IDA Articles. The prohibitions define - according to Shihata - the six distinct yet intertwined conditions for the Bank's operations. ${ }^{215}$ The two rules out of these requirements are of particular importance in our case. The first one refers to prohibition of interference in the political affairs of a member, whereas the second one prohibits taking non-economic considerations into account during decision-making. ${ }^{216}$ Tax issues are highly political in nature because they require, first of all, answering questions, such as who and to what extent should contribute to that particular country's public finance, that affect the distribution of wealth within a society. Any activities undertaken in the field of taxation could therefore be an activity prohibited by the Bank's own Articles owing to this general nature of tax issues. And since the Bank has the duty to act in conformity with its Articles, neglecting these prohibitions would imply 'for the Bank acting 'ultra vires' or beyond its legal powers. ${ }^{217}$ The Bank's former General Counsel and his successive colleagues of the Legal Vice Presidency seem to have always been conscious of such consequence and advised to approach such issues with due caution. ${ }^{218}$ However, they did not completely deny the possibility of involvement of the Bank in activities that are related to political issues. ${ }^{219}$ Although I agree with their latter opinion, I think that it is possible to make a clear distinction between the allowed and not allowed

214. Shihata (1991), above n. 123, at 65-6.

215. Id., at 66-7

216. Art. III (5[b]) and Art. IV (10) of IBRD Articles. Also Art. V (1[g]) and Art. $V(6)$ of IDA Articles.

217. Shihata (1991), above n. 123, at 66-7.

218. Legal Vice Presidency - World Bank (2005), above n. 106, at 17.

219. Id., 16-7. involvements of the Bank in a tax-related activity. In my opinion, such a distinction could be made not on the basis of the nature of the issues concerned, but on that of the degree and nature of the involvement. For example, a tax-related conditionality in a lending instrument will be problematic if it concerns a pre-selected choice that should be implemented by the client, while an advisory activity that discusses technical issues of taxation should not be seen as a prohibited activity. Anyway, since the constituent organs of the Bank carrying out its mandates are allowed to interpret the mandates themselves, it is possible that they have concluded based on this flawed provision in the Articles that these kinds of activities do not fall under the prohibited political activity. And since no cases of objection by members - notwithstanding the question whether or not they had an opportunity to do so - are known, the Bank could, oddly enough, rightfully assume that its decisions to expand were legal - all the more notably as other decisions to expand into the non-tax fields that were taken earlier within the Bank could also act as 'precedents' for the Bank's expansions into the tax field. This leads, therefore, to the conclusion that both the decisions of the Bank to expand were legal. In the following section, I provide an answer to the second question that was posed in the introduction of this article.

\subsection{Implications for the Bank's Legitimacy}

According to Martti Koskenniemi, legitimacy is a notion of recent vintage that was developed by liberal political theory in order 'to enable criticism of social institutions without relying on earlier routes of critical thought which had been traveled to the end and in the process had lost much of their respectability'. ${ }^{220}$ Whatever purpose the creators of this notion had for it, it has now become one of the most widely used concepts with an application and utility beyond the realm of this theory. However, the meaning of this concept is vague, and consequently it is normatively defined in several different ways. In legal or political literature, the most widely accepted meaning is the reason why someone follows a rule. This meaning is, however, too broad without further clarifications as there are other factors that can yield rule-following or compliance with a rule. ${ }^{221}$ In addition to legitimacy, one comes across in the literature three other factors of compliance with a rule, which are self-interest, coercion and rational persuasion. From all these means of compliance, the legitimacy appears to have a quality that creates voluntary compliance with a rule in the absence of these three alternative sources of compliance. But the question could be raised as to why anyone without being obliged to or being rationally persuaded oreven having a self-interest in the outcome would simply follow a rule. Whereas it is clear to every-

220. M. Koskenniemi, 'Book Reviews and Notes', American Journal of International Law 86, at 175 (1992).

221. D. Bodansky, 'The Legitimacy of International Governance: A Coming Challenge for International Environmental Law', 93 American Journal of International Law 596, at 602-3 (1999). Franck does not say that with much wording. Buchanan and Keohane do the same. 
one that other three bases of compliance can induce compliant behaviour, more is needed to understand what legitimacy is.

Daniel Bodansky and Rudiger Wolfrum observed in this regard that legitimacy is not exclusively a 'reason' for compliance, but also a 'justification' of the exercise of (any kind of) authority. ${ }^{222}$ Yet this observation does not seem to convey that legitimacy and justification are coextensive. Such an observation would be, otherwise, narrow as it, on the one hand, would neglect the difference between the meanings of these two concepts and, on the other hand, would suppose one-sided action from the 'governor' to the 'governed'223 to substantiate its claim for authority. Monica Hlavac warned, therefore, rightfully of this kind of 'Kantian tendency' based on the A. John Simmons's conclusion that legitimacy judgment differs from the justification judgment. ${ }^{224} \mathrm{Sim}-$ mons mentioned two reasons for it. First, a person would require more than a justification before he accepts restrictions on his natural freedom. Second, a justification does not in itself impose obligations on people. Consequently, Hlavac notes that legitimacy derives from a two-way significant relationship between the one that make decisions and the ones that are affected by its decision. ${ }^{225}$ However, this proposition of Hlavac is not completely new as any normative theory on legitimacy assumes some kind of relationship between the agent and its principal. The agent is in this case always the one who has the right to govern or rule, whereas the principal differs in each theory - being the god, sovereign states, constituencies or affected people.

We are, however, not readily equipped with the above to assess the legitimacy of any international institution or its output as they only draw the outer lines of the notion of legitimacy. Consequently, it is imperative to do more exploration to find out when exactly we can speak of legitimacy or what the possible yardstick - sometimes called 'sources',26 'variables', 227 'elements'228 or 'stand$\operatorname{ards}^{\prime 229}$ - of legitimacy is. Many different yardsticks for legitimacy are mentioned by various scholars belonging to many different traditions of international legal and international relations scholarships. They are usually categorised as source-, procedure- and outcome-based

222. D. Bodansky, 'The Concept of Legitimacy in International Law', in R. Wolfrum \& V. Roben (eds.), Legitimacy in International Law (2008) 309, at 312; Bodanksy (1999), above n. 221, at 603; and R. Wolfrum, 'Legitimacy of International Law from a Legal Perspective: Some Introductory Considerations', in R. Wolfrum and V. Roben (eds.), Legitimacy in International Law (2008) 1, at 6.

223. I borrow these terms from Brunnée and Toope. See J. Brunnée and S.J. Toope, 'International Law and Constructivism: Elements of an Interactional Theory of International Law', 39 Columbia Journal of Transnational Law 19 (2000).

224. M. Hlavac, 'A Developmental Approach to the Legitimacy of Global Governance Institutions', in D.A. Reidy and W.J. Riker (eds.), Coercion and the State (2008) 203, at 212-3

225. Id., at 212-4

226. Id., at 204.

227. Brunnée and Toope (2000), above n. 223, at 53

228. Wolfrum (2008), above n. 222, at 6.

229. A. Buchanan and R.O. Keohane, 'The Legitimacy of Global Governance Institutions', in R. Wolfrum and V. Roben (eds.), Legitimacy in International Law (2008) 25, at 28. ones. ${ }^{230}$ In what follows, I explore some of the most authoritative theories forwarded within international law and international relations scholarships.

Pursuant to the dominant theoretical tradition of international legal scholarship, states legitimise activities of IIs by giving their consent to their activities. In relation to multilaterally established IGOs, this consent is given by the states either, at the onset, through signing of a treaty establishing an IGO or, later, through accessing to the membership of that IGO. ${ }^{231}$ The state consent has such a legitimising effect as, on the one hand, states have a 'thick' legitimacy on the national level ${ }^{232}$ and, on the other hand, they are the only - for the most part ${ }^{233}$ players in the international arena. This arena is horizontal in nature ${ }^{234}$ and distinct from the national playfield owing to its lack of Austinian power. ${ }^{235}$ Consequently, state consent is the only standard of legitimacy at the international level. All the traditional sources of international law ${ }^{236}$ - (internationally recognised) general principles of law, treaties and international customary law can therefore be led directly or indirectly to state consent. $^{237}$ Even the extensive decision-making power of IGOs also finds its origin in the consent of states. ${ }^{238}$ This consent not only has a legitimising effect for the rules of international law, but also legally binds states to these rules of international law. ${ }^{239}$ So, as long as IGOs stay within the limits of their mandate defined in their

230. Wolfrum (2008), above n. 222, at 6; Bodansky (1999), above n. 221, at 612; T.M. Franck, Fairness in International Law and Institutions (1995), at 7-8; and Hlavac (2008), above n. 224, at 204.

231. E. Hey, 'Sustainable Development, Normative Development and the Legitimacy of Decision-Making', 12 Netherlands Yearbook of International Law 3, at 16 (2003); J. Klabbers, 'The changing image of IOs', in J. Coicaud and V. Heiskanen (eds.), The Legitimacy of IOs (2001) 221, at 224-36; and Bodansky (1999), above n. 221, at 604

232. N. Krisch, Beyond Constitutionalism: The Pluralist Structure of Postnational Law, (2010), at 297

233. Exceptions concern humanitarian law and international criminal law, which directly address individuals.

234. All members are considered to be equal to each other.

235. Austin noted in his book The Province of Jurisprudence Determined (1832) that law is a command of a sovereign to its subjects. See T.M. Franck, 'Legitimacy in the International System', 4 Americal Journal of International Law 705 (1988), at 706, fn. 3.

236. As mentioned in the statute of International Court of Justice.

237. The state gives its explicit consent to treaties by concluding them, whereas in the case of customary international law and internationally recognized principles the implicit consent is conceived to be given by state practice. See Wolfrum (2008), above n. 222, at 7-9 and E. Hey, Teaching International Law: State-Consent as Consent to a Process of Normative Development and Ensuing Problems, (2003).

238. Scholars identify two types of state consent: general and specific. The authority of sources of international law is based on a specific state consent, while the authority of IOs is based on the general consent. Bodansky (1999), above n. 221, at 604-5. This general state consent thus forms the basis of the law of IOS, which is reflected in two opposing doctrines: the implied powers doctrine and the principle of attribution. Klabbers (2001), above n. 231, at 224-36. The 'implied powers' doctrine is developed by the International Court of Justice in its 11 April 1949 case Reparation for Injuries Suffered in the Service of the United Nations (ICJ Reat 1949, at 180). This doctrine is based on the principle of effectiveness. In short, it dictates that every 10 has implied powers, which are needed for reaching its purposes and exercising its explicit powers. Alvarez (2001), above n. 182, at 116-7 and 121 .

239. Hey (2003), above n. 231, at 15 
founding documents, their activities are legal and at the same time legitimate.

For a long time, this theoretically pre-supposed conflation of the notions of legitimacy with the notion of legality through state consent corresponded not only with the reality of that time, but appeared to be highly practical and efficacious in international legal practice. In the recent decades, however, the rise of global problems in conjunction with the legal empowerment of international institutions based on considerations of the 'principle of (institutional) effectiveness ${ }^{240}$ has led to a shift of (a large part of) the national decision-making authority to the international level. ${ }^{241}$ Since the consensual-decision making on the international level is, at the same time, being replaced by flexible law-making approaches, ${ }^{242}$ it results eventually in the break or prolongation of the legitimacy chain towards the people who are affected by the decisions taken on the international level. ${ }^{243}$ Consequently, a growing group of people within and beyond legal academia began to discern discrepancies between the fundamental assumptions of this dominant paradigm and the reality. This discrepancy raised the question of adequacy of the state consent as the source of legitimacy of international law. Accordingly, they proposed many different solutions for the lack of legitimacy that ensues from this discrepancy. Although these people are a heterogeneous mixture of people, they could, broadly speaking, be divided into two main distinct groups: 'nationalists,' or those who propose to contain and reverse the international developments, and 'internationalists,' or those who propose to accommodate these developments. Both groups, however, agree with each other that the state consent would have sufficed as long as the two distinctive layers of the global legal order - international and domestic - had remained in two separate operational spheres. ${ }^{244}$ As to the second group, it could be further divided into three subgroups. The first subgroup emphasises the emergence of a truly global political and legal order and, therefore, denies the suitability of the dominant paradigm in its entirety by proposing to replace it with a completely different one. ${ }^{245}$ In contrast to it, the second subgroup discerns only a partial convergence of the international and domestic layers of the global order owing to the rise of global problems. ${ }^{246}$ Consequently, they propose to repair legitimacy deficits that resulted from it in certain parts of international law development by either adapt-

240. This principle forms the basis of the implied powers doctrine. See above n. 238.

241. All scholars seem to observe this process.

242. Bodansky (1999), above n. 221, at 606.

243. Wolfrum (2008), above n. 222, at 20

244. Krisch (2010), above n. 232, at 297.

245. To this group of scholars belong constitutionalists and pluralists. The seminal book written by the former group is: J. Klabbers, A. Peters \& G. Ulfstein, The Constitutionalization of International Law (2009). For the vision of pluralists, see Krisch (2010), above n. 232.

246. Hey (2003), above n. 237; E. Hey, 'International Institutions', in D. Bodansky, J. Brunnée \& E. Hey (eds), The Oxford Handbook of International Environmental Law (2008) 749, at 751; and Wolfrum (2008), above n. 222, at 5. Ellen Hey calls these global problems 'common interest' problems, which concern everyone in the world. ing the process of international norm development ${ }^{247}$ or improving the governance structure of international institutions that create these norms. ${ }^{248}$ The last subgroup tries to amend the legitimacy gap by improving the domestic 'legitimacy chain' by 'strengthening the national parliamentarian influence on the conduct of international relations which is traditionally thought to be domain of governments'. ${ }^{249}$

The number of theories and their differences between them, however, do not allow a discussion of all details and merits of these theories here. Nonetheless, this classification enables me to make a rough judgment on possible implications of the two informal decisions for the Bank's legitimacy. Whereas I think that we could be sure that the two decisions have no implications if we apply the dominant paradigm of international legal scholarship, such a judgment cannot be made on the basis of other theoretical traditions that are gaining more and more influence within and beyond academia. Of course, the Bank may feel itself safe with the dogma of the dominant theory and think that it does not need to take any actions to improve this legitimacy chain. But it is better to play safe and take provisionary measures since the tendency inclines to the direction of bringing the ones that have the 'right to rule' closer to the people that are 'being ruled'. This direction of movement seems to be visible not only in the aforementioned new theories proposed by the scholars, but also on the demands of non-governmental organizations and the will of the political leaders belonging to the G20 with their frequent calls addressed to the four major IGOs. Although the G20 comprise non-elected officials of some twenty economies in the world, it is, nonetheless, aimed at shortening the chain of legitimacy at least with regard to their constituencies.

It seems that the Bank is also aware of this general movement as it has undergone owing to these new calls for legitimacy some institutional facelift in recent decades. The most recent and important of these adjustments concern the revision of the previously mentioned distribution of voting power in 2010. Moreover, one can mention the establishment of the Bank's 'Inspection Panel' in 1993. This internal, yet independent, accountability mechanism investigates, on the basis of a request from project-affected people, whether or not the Bank, as a result of a failure to follow its operational policies and procedures, adversely affects or is likely to affect by its action or omission the rights and interests of the people that have submitted complaints. ${ }^{250}$ Furthermore, a big step into the direction of transparency was made with the introduction of the Policy on Access to Infor-

247. Wolfrum (2008), above n. 222, at 4. The representatives of this group are analytical positivists as Franck and constructivists as Brunneé and Toope.

248. Representatives are, among others, Buchanan, Keohane and Hlavac.

249. Wolfrum (2008), above n. 222, at 5.

250. Section 12 of Resolution No. IBRD 93 and Resolution No. IDA 93 establishing the World Bank Inspection Panel, 22 September 1993. 
mation on 1 July 2010. ${ }^{251}$ This information policy replaced the Bank's old Information Disclosure policy of more limited scope. ${ }^{252}$ As a result of two subsequent modifications of this policy, respectively in 2013 and 2015, the public has now access to information about projects under preparation, projects under implementation, analytic and advisory activities, and Board proceedings. ${ }^{253}$ Although these developments are to be cheered, the changes largely focus on improvements of the Bank's governance structure, which depends on the willingness of the large shareholders of this IGO. Furthermore, the impact of these changes was of limited scope since these developments did not aim to bring a radical reform of the governance structure. For example, the 2010 reform resulted only in a substantial increase in the voting power of a few economies such as China, India and Brazil, while it led to a negligible increase - and even decrease in some cases - in the voting powers of some other developing members. ${ }^{254}$

It is not clear whether or not the Bank's policy dialogues and recommendations in its policy-based loans have involved and still involve a pre-selected choice containing an ultimate tax policy norm that should be implemented by the borrowing member. It looks like this was the case in the past if we consider the Bank's adjustment loans with tax conditionality. ${ }^{255}$ However, the Bank's recently adjusted Bank Policy (BP) and Operational Policy (OP) 8.60 suggest otherwise. ${ }^{256}$ According to Paragraph 9 of the BP 8.60: 'In carrying out dialogue with a Member Country, the Bank advises it to consult with and engage the participation of key stakeholders [emphasis added] in the country in the process of formulating its development strategies. Key stakeholders include social groups directly affected by the operations, as well as public sector, private sector and donor organizations relevant to the operation. For a development policy operation, the Member Country draws on this process of strategy formulation to determine, in the context of its constitutional and legislative framework, the form and extent of consultations and participation in preparing, implementing, and monitoring and valuating the operation.' However, such a consultation does not exclude the imposition of tax-related conditions from the Bank, because the borrowing member state will need to negotiate with the Bank on the loan conditions or conditionality after its consultation with the so-called key stakeholders. And it is even more the case since the donor organisations relevant to the operation are also mentioned as such stakeholders. If in practice such an imposition takes place then it implies shift of the decision-making authority from developing members to the international level. Although such a shift might be nec-

251. <www.worldbank.org/en/access-to-information/overview\#1> (last visited 9 October 2017)

252. Id.

253. Id.

254. See above n. 64 and 65

255. More research is needed on this matter

256. Bank Policy, 'Development Policy Financing', OPS5.02-POL.105, 2 August 2017 (Effective from 13 July 2017). essary for tackling the international tax problems, a topdown approach is not the only way of reaching that shift and will even render the shift illegitimate. And since having a legitimate authority means in part having lower costs of implementation, this lack of legitimacy vis-à-vis its client members will eventually lead to increased costs of implementation for the Bank, its main shareholders and eventually to the international community.

\section{Conclusion}

The Bank has now become one of the prominent players in the field of taxation. Two informal decisions to expand that were taken in the past have contributed to the Bank's current position. The first one was taken as early as the late 1970 s. As a result of this decision, the Bank expanded its activities into the domestic tax field of its clients and has subsequently evolved as their colegislator or legislative partner. It performed its co-legislative role by attaching conditionality to its adjustment loans at times when its clients were desperately in need of financial resources. In other cases, it appeared as a legislative partner for its clients through its frequently held policy dialogues and on-demand advisory activities. After the outbreak of the 2008 financial and economic crisis, owing partly to the enhanced attention of the G20, the Bank took its second decision to expand. This time the Bank expanded into the international tax field. As a result, international tax issues became another component of the Bank's tax-related work. Yet questions could be raised whether these informal decisions which in some cases result in significant constraint of parliamentary authority in the Bank's client member states - were legal, and if so, what implications, if any, they have for the Bank's legitimacy. Based on the Bank's Articles and the current doctrines of international law, it could be concluded that these informal decisions were legal, even though the Bank's Articles contain a serious deficiency with regard to the provision of competent authority for interpretations. The answer to the other question, however, is not straightforward as much will depend on the normative theory that is chosen to assess the Bank's legitimacy. Nevertheless, the tendency inclines to the direction of bringing the ones that have the 'right to rule' closer to the people that are being ruled. This direction of movement seems to be visible not only in the aforementioned new theories proposed by the scholars, but also on the demands of non-governmental organizations, the will of the political leaders belonging to the G20, and the Bank's own and its main shareholders' reform efforts. However, there is a need for more reforms in order to make the Bank more legitimate. For that purpose, not the top-down but the bottom-up approach should be followed if the Bank wishes to be legitimate vis-à-vis its client members and with that reduce the costs of implementation for the Bank, its main shareholders and eventually to the international community. 